\title{
Radicals and Radical Ions as Intermediates of Electron Transfer Processes through Peptides
}

\author{
Bernd Giese ${ }^{\star}$, Sonja Eckhardt, Miriam Lauz, Jian Gao, and Min Wang
}

\begin{abstract}
Electron transfer (ET) through peptides and proteins is a key biochemical process, which involves radicals and radical ions as reactive intermediates. We have developed an assay that allows us to study this fundamental chemical reaction.
\end{abstract}

Keywords: Electron transfer $\cdot$ Hopping $\cdot$ Peptide $\cdot$ Radical ion

\section{Assay}

Long-distance electron transfer (ET) through peptides, proteins and enzymes plays an important role in living organisms. ${ }^{[1]}$ More than a decade ago we studied related reactions in DNA and concluded that long-distance ET through DNA can occur only as a multistep hopping reaction. ${ }^{[2]}$ To answer the question whether an analogous hopping process also occurs in peptides, ${ }^{[3]}$ we have developed assay 1a that is suitable to address this issue. ${ }^{[4]}$ Furthermore it allows the determination of the influence of side chains, charges and conformations on the ET processes of these biopolymers. Peptide 1a consists of nine amino acids (Fig. 1): tyrosine at the $\mathrm{N}$-terminal end acts as electron donor, the dialkoxyphenylalanine at the C-terminal end is the precursor of the electron acceptor, and the amino acid with the side chain $\mathrm{X}$ in the center of the peptide can be varied in order to detect the influence of side chains on the ET reaction. These three amino acids are separated from each other by triproline spacers.

The dialkoxyphenyl radical cation $\mathbf{5}$, which acts as electron acceptor, is generated from its precursor $\mathbf{2}$ by laser flash photolysis. ${ }^{[5]}$ The first ground state intermediate is radical 3 , whose $\beta-\mathrm{C}-\mathrm{O}$ bond is cleaved in a heterolytic fashion, yielding radical cation 4 . We have demonstrated the generation of radicals like 3 by ESRspectroscopy, ${ }^{[5 b]}$ and the formation of a radical cation like 4 by chemically induced dynamic nuclear polarization (CIDNP). ${ }^{6]}$ Monte-Carlo simulations showed that the heterolytic cleavage $\mathbf{3} \rightarrow \mathbf{4}$ is only possible in the presence of polar solvents. ${ }^{[5 b]}$ The last step of the reaction sequence is the oxidation of the aromatic ring to radical cation $\mathbf{5}$, which can be detected by UV/VIS spectroscopy $\left(\lambda_{\max }=450 \mathrm{~nm}\right){ }^{[4]}$

According to the mechanism shown in Scheme 1, laser flash photolysis of 1 yields peptide 6, which contains the active electron acceptor at the C-terminal amino acid. If ET occurs through peptide 6, tyrosine at the N-terminal end will be oxidized to the tyrosyl radical $(6 \rightarrow 7)$. This process can be followed by transient absorption spectroscopy, observing the decreasing absorption of the dialkyl radical cation $\left(\lambda_{\max }=450 \mathrm{~nm}\right)$ as well as the increasing signal of the tyrosyl radical $\left(\lambda_{\max }=408 \mathrm{~nm}\right)$. The driving force for this ET step is the difference of the oxidation potentials (about $0.3 \mathrm{eV}$ ) be- tween the electron acceptor and the electron donor. ${ }^{[4]}$

As shown by CD-spectroscopy the two triproline spacers induce the conformation of a polyproline II (PPII) helix into the peptide, which does not change up to $80^{\circ} \mathrm{C}$. The NMR spectra demonstrate that $80 \%$ of the proline amide bonds are present in trans-conformation, and molecular dynamic calculations predict the stretched conformation $\mathbf{1 b}$ (Fig. 1) as the major one of this assay. ${ }^{[4,7]}$ In such a system the distance between the electron donor and the electron acceptor is approximately $20 \AA$. Fluorescence quenching experiments of a hexapeptide containing four prolines have shown that the conformational rigidity of these PPII helices is so high that an encounter of the $\mathrm{N}$ - with the $\mathrm{C}$-terminal amino acid is slower than $2 \times 10^{5} \mathrm{~s}^{-1}$. ${ }^{[8]}$ Therefore an experimentally detected ET of $\mathbf{6} \rightarrow 7$, which is faster than about $5 \times 10^{5} \mathrm{~s}^{-1}$, can occur through the stretched peptide backbone.

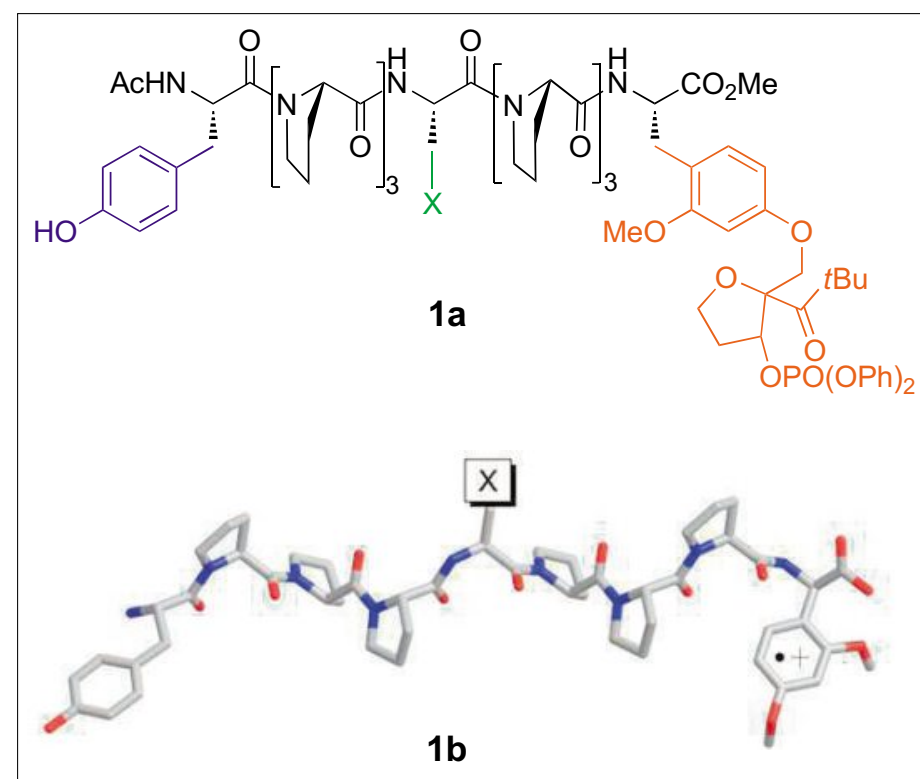

Fig. 1. Peptide assay used for the ET experiments. $\mathbf{1 b}$ shows a polyproline (PP) II helix, which is the dominant conformation of 1a. 


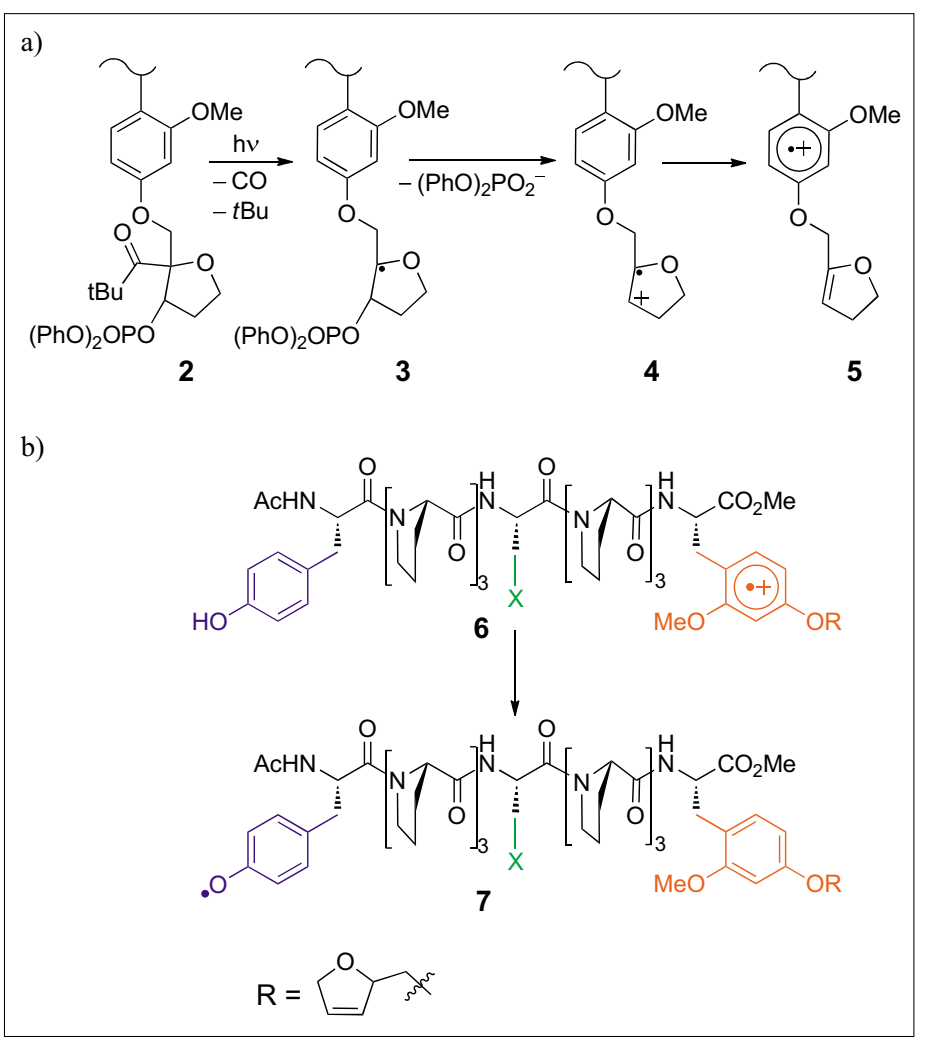

But the time window is not only limited by the conformational stability of the peptide backbone but also by the formation time of the electron acceptor $(\mathbf{1 a} \rightarrow \mathbf{6})$, the lifetime of the reactive intermediates, and the intermolecular ET rates (reaction between 6 and remaining 1a). Under the reaction conditions of our ET experiments (solvent: $\mathrm{CH}_{3} \mathrm{CN}: \mathrm{H}_{2} \mathrm{O}=3: 1$, temperature $=20{ }^{\circ} \mathrm{C}$, neutral $\mathrm{pH}$ ) we have measured a formation rate $\mathbf{1 a} \rightarrow \mathbf{6}$ of $3 \times 10^{8} \mathrm{~s}^{-1}$ by laser flash irradiation. [9] Under the same reaction conditions the life time of the aromatic radical cation $\mathbf{5}$ (trapping by the solvent) and of tyrosyl radical 7 (dimerization) was measured to be longer than $0.1 \mathrm{~ms}^{[10]}$ However, the bimolecular ET reaction between radical cation $\mathbf{6}$ and the starting material 1a, which also generates tyrosyl radicals, is about $4 \times 10^{5} \mathrm{~s}^{-1}$ (pseudo first order) for a $1 \mathrm{~mm}$ solution of the starting material.[11] We need these relatively high concentrations for our experiments even with a powerful excimer laser (100-150 mJ per pulse) because of the weak extinction coefficients of the starting ketone group of $\mathbf{1 a}$, as well as the reactive intermediates in $\mathbf{6}$ and 7. Therefore the time window of our assay for exact measurements of intramolecular ET through peptides is about $10^{6}$ to $10^{8} \mathrm{~s}^{-1}$.

\section{Electron Hopping}

Single-step ET (superexchange) between the electron donor (tyrosine) at the $\mathrm{N}$-terminal end and the electron acceptor
Scheme 1. a)

Formation of the electron acceptor. b) Formation of the tyrosyl radical during ET through peptide 6 . (radical cation of the dialkoxyphenylalanine) at the C-terminal end of peptide $\mathbf{6}$, which are about $20 \AA$ apart, is expected to be slower than $10^{6} \mathrm{~s}^{-1}$ because of the distance dependence of ET rates described by Eqn. (1), where $k_{E T}$ is the ET rate between donor and acceptor, $k_{0}$ the rate at van der Waals contact distance, $\beta$ the attenuation factor and $r_{p 4}$ the donor/acceptor distance. ${ }^{12]}$ Typical $\beta$-values for proteins are between 1.0-1.5, and $k_{0}$ is in the order $10^{13} \mathrm{~s}^{-1}[13]$

$$
k_{E T}=k_{0} \exp \left(-\beta r_{D A}\right)
$$

According to these data one would expect rates in the order of $10^{5} \mathrm{~s}^{-1}$ or less for single step (superexchange) ET in peptide 6, where the donor/acceptor distance is about $20 \AA$. It is therefore not surprising that our experiments with peptides carrying an alkyl side chain $X$ at the central amino acid of $\mathbf{6}$, which cannot be oxidized by the aromatic radical cation and cannot induce a two-step hopping mechanism, was too slow to be measured exactly by our assay: the intermolecular ET was as fast as the ET through the peptide bonds. ${ }^{[4 a]}$ This is in accord with experiments of Isied et al., who measured an ET rate of $1 \times 10^{5}$ $\mathrm{s}^{-1}$ for a system where the electron donor and the electron acceptor are separated by six prolines. ${ }^{[14]}$ In order to study ET rates via a hopping process we introduced trimethoxyphenyl as a side chain $\mathrm{X}$ in our assay 8 (Scheme 2). The redox potentials of the 2,4-dimethoxy- and 2,4,6-trime- thoxyphenylalanine are nearly the same. ${ }^{[4]}$ Therefore the radical cation in $\mathbf{9}$ should be able to oxidize the central amino acid and to generate the aromatic radical cation $\mathbf{1 0}$. This process can be followed spectroscopically as radical cation $\mathbf{1 0}$ has its $\lambda_{\max }$ at $550 \mathrm{~nm}$. The subsequent ET step is the oxidation of tyrosine that generates the tyrosyl radical $\left(\lambda_{\text {max }}=408 \mathrm{~nm}\right)$ after deprotonation $(\mathbf{1 0} \rightarrow 11)$.

The experiments were carried out by laser flash photolysis (excimer laser, 100 $150 \mathrm{~mJ}$ per pulse) of $2-5 \mathrm{~mm}$ solutions of 8 in $\mathrm{CH}_{3} \mathrm{CN}: \mathrm{H}_{2} \mathrm{O}=3: 1$ at $20{ }^{\circ} \mathrm{C}$ and neutral $\mathrm{pH}$. Snapshot experiments $40 \mathrm{~ns}$ after the laser flash have demonstrated that all three reactive intermediates of $\mathbf{9 , 1 0}$ and $\mathbf{1 1}$ are observable ${ }^{[4 a]}$ and we could measure their concentration at different times. ${ }^{[11]}$ The experimental results are shown in Fig. 2.

From the data of Fig. 2 it is obvious that ET $(\mathbf{9} \rightarrow \mathbf{1 1})$ occurs as a consecutive reaction: by increase of the reaction time the concentration of the radical acceptor 9 decreases, the oxidized intermediate $\mathbf{1 0}$ is formed in a small, nearly steady state concentration, and the amount of the oxidized electron donor 11 increases. Obviously the side chain of the central aromatic amino acid is oxidized during ET $(\mathbf{9} \rightarrow \mathbf{1 0})$. We have referred to amino acids, which act as stepping stones in an ET hopping process as relay amino acids. ${ }^{[4 a]}$ The absolute rates of the individual ET steps differ from each other by a factor of 10 , which is caused by the difference of the free reaction enthalpies. ${ }^{[11]}$ The thermodynamic energy change of the ET step between the trialkoxy- and the dialkoxyphenylalanine is close to zero and the rate $k_{1}$ of the first hopping step is ten times slower than the exergonic (about $0.3 \mathrm{eV}$ ) ET between tyrosine and the radical cation of the trialkoxylated phenylalanine $\left(k_{2}\right)$. The absolute rate of $3 \times 10^{7} \mathrm{~s}^{-1}$ for the exergonic ET step via three prolines is comparable with measurements of Isied et al., ${ }^{[14]}$ who attached ligand/metal complexes as donor/acceptor systems to the $\mathrm{N}$ - and the C-terminal end of PPII helices. If we increased the number $\mathrm{n}$ of prolines between tyrosine as electron donor and the aromatic radical cation as electron acceptor the ET rate decreased from $3 \times 10^{7}$ for $\mathrm{n}=3$ to $4 \times 10^{6} \mathrm{~s}^{-1}$ for $\mathrm{n}=4$ and $6 \times 10^{5} \mathrm{~s}^{-1}$ for $\mathrm{n}=5$. $^{[15]}$ This shows the distance effect on the ET rate, and is in accord with measurements of Isied et al. ${ }^{[14]}$

\section{Relay Amino Acids}

Variation of the side chain $\mathrm{X}$ in assay $1 \mathrm{a}$ and laser flash photolysis experiments showed that not only heteroaromatic but also sulfur-containing amino acids can function as relay amino acids during an ET process (Fig. 3). ${ }^{[4 \mathrm{c}, 16]}$ 


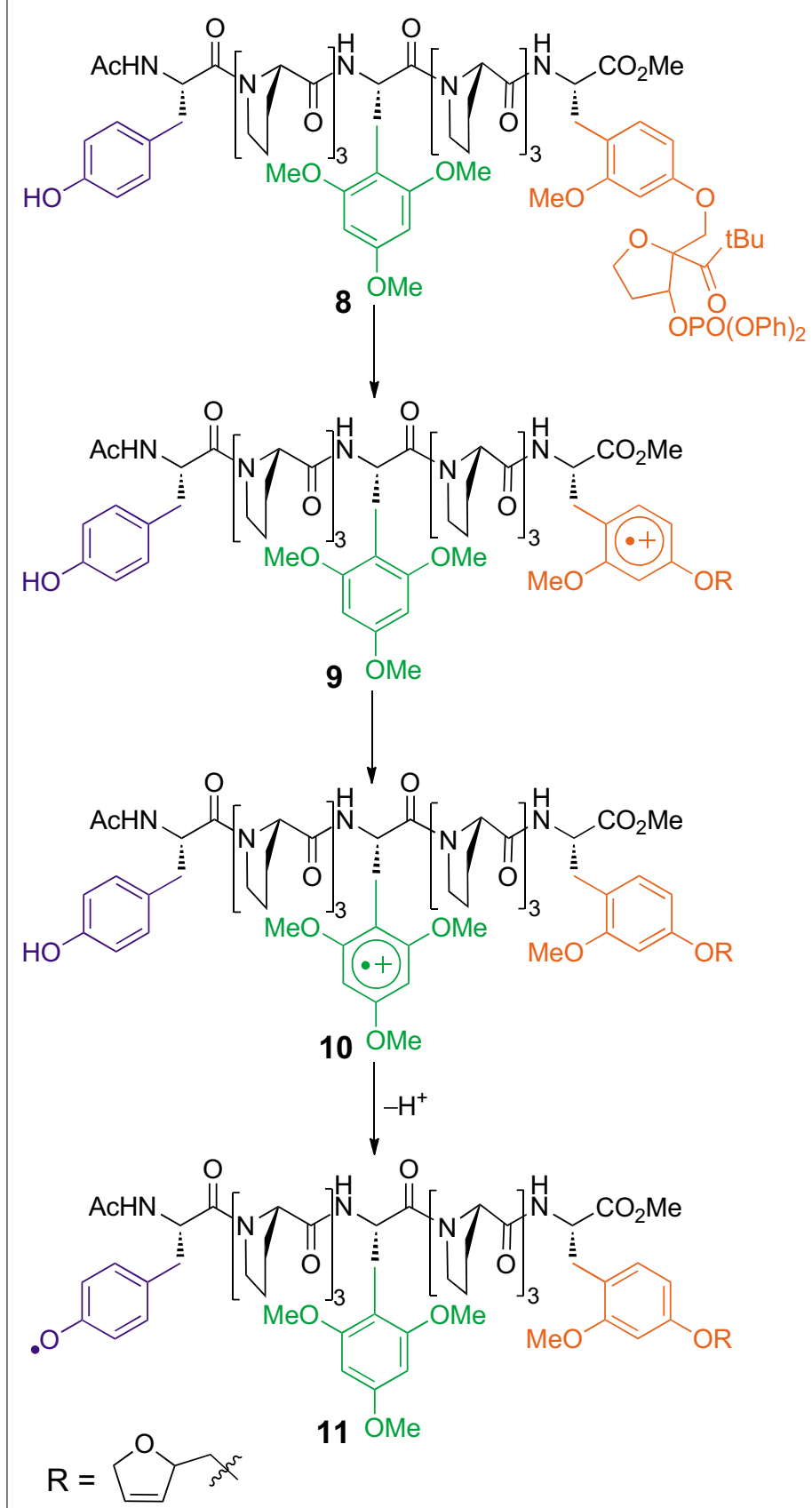

Scheme 2. Laser irradiation of peptide 8 and ET through the peptide in a hopping mechanism.

Amino acids with an $\mathrm{O}-\mathrm{H}-$ or $\mathrm{N}-\mathrm{H}$ containing side chain become acids after oxidation. Their deprotonation generates neutral radicals that are much weaker oxidants than the respective radical cations and therefore retard or even stop further ET steps. Nature 'knows' this effect and has several ways of taking advantage of it. [1b] Either, amino acids as proton traps are positioned close to the relay amino acids so that the proton can be donated back during the subsequent ET step, or the side chain of the relay amino acid is protected from water by the surrounding protein, preventing deprotonation. Examples are ribonucleotide reductase where glutamate is close to the relay amino acid tryptophan, ${ }^{[17]}$ photosystem II where glutamine protects

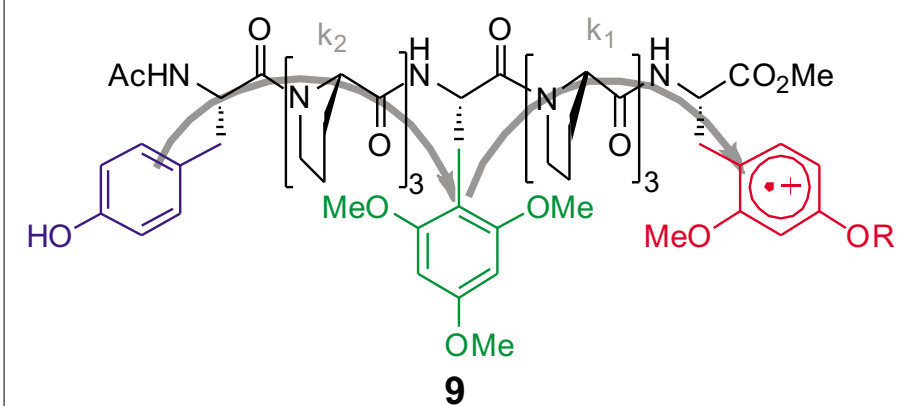

$$
k_{2}=3.0^{*} 10^{7} M^{-1} s^{-1} \quad k_{1}=3.3^{*} 10^{6} M^{-1} s^{-1}
$$

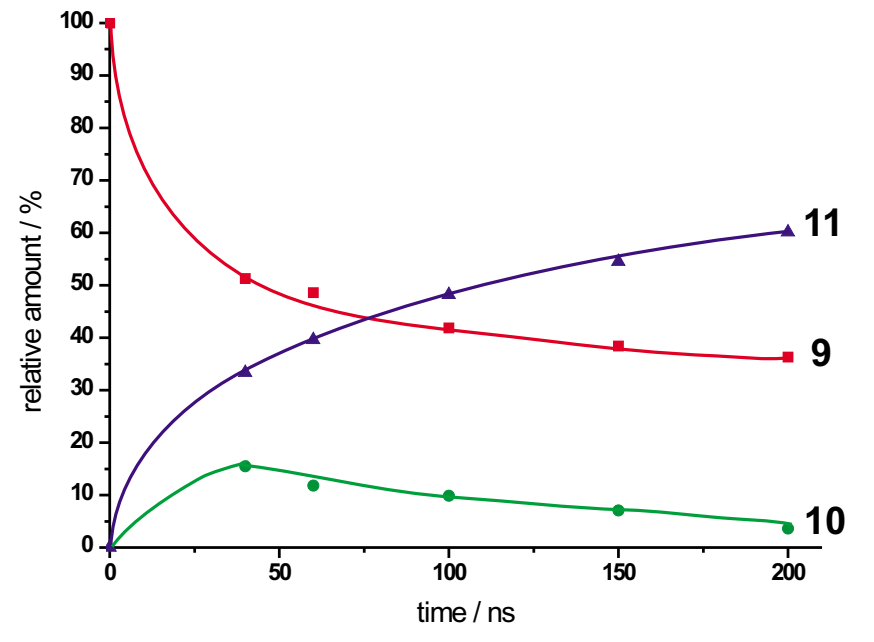

Fig. 2. Electron hopping in peptide 9. The graph shows the concentration change of the reactive intermediates.

a)<smiles>N[C@@H](Cc1ccc(O)cc1)C(=O)O</smiles><smiles>N[C@@H](CC1=C2C=CC=CC2NC1)C(=O)O</smiles><smiles>N[C@@H](Cc1cnc[nH]1)C(=O)O</smiles>

L-Tyrosine

L-Tryptophan

L-Histidine<smiles>N[C@@H](CS)C(=O)O</smiles><smiles>N[C@@H](CSSC[C@H](N)C(=O)O)C(=O)O</smiles>

$\mathrm{H}_{2} \mathrm{~N} \smile \mathrm{CO}_{2} \mathrm{H}$<smiles>CCCCCCCCCCCCCC</smiles>

L-Cysteine

L-Cystine

L-Methionine

b)
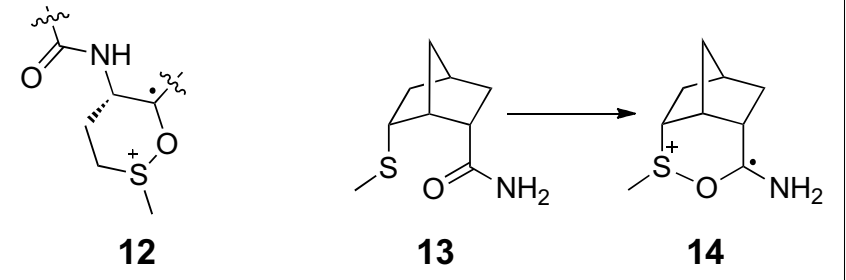

Fig. 3. a) Amino acids that can function as relay amino acids. b) Neighbor group effect with methionine as relay amino acid. 


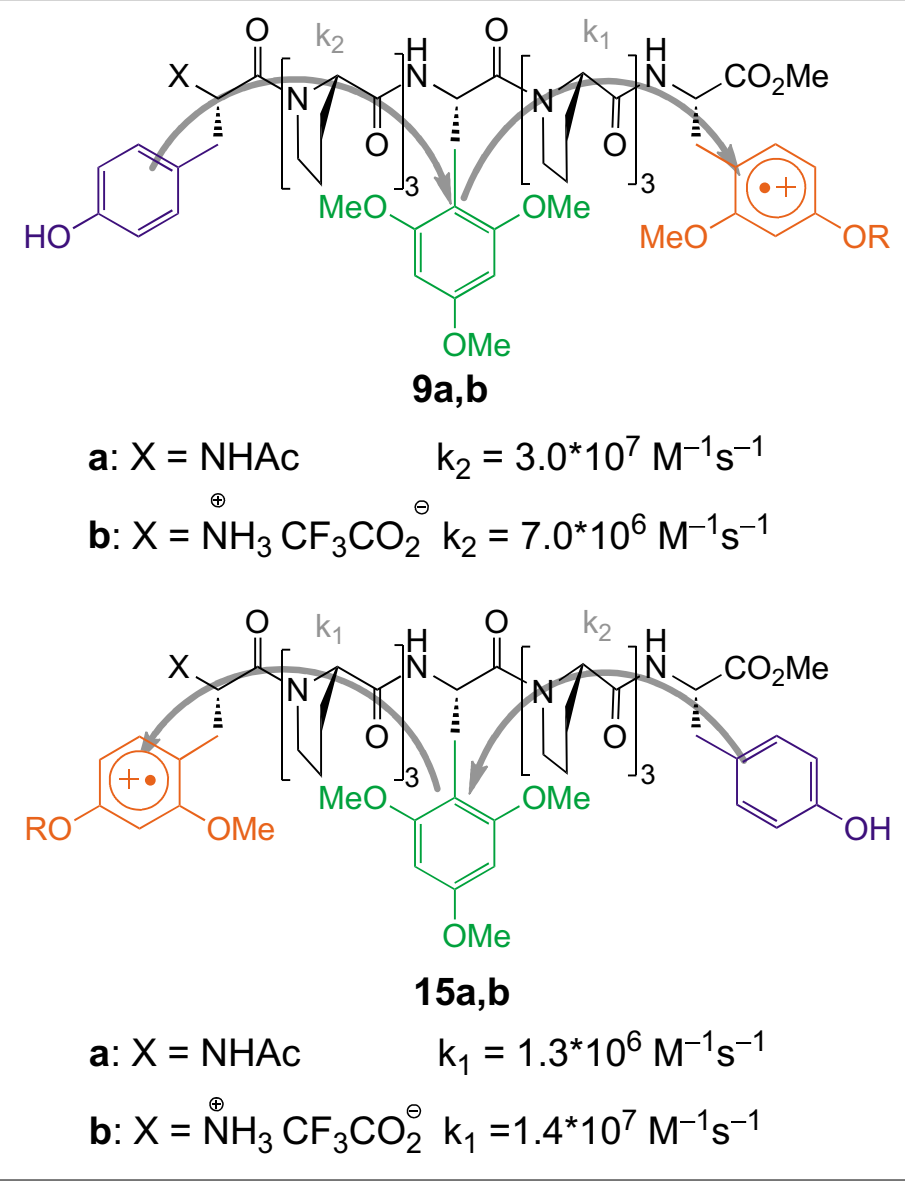

Fig. 4. Influence of a positive charge on ET rates.

tyrosine, ${ }^{[18]}$ and photolyase where the positive charge can hop over several tryptophans that are not exposed to water. ${ }^{[19]}$ Interestingly, methionine also acts as relay amino acid although simple dialkylthioethers have high redox potentials (about $1.4 \mathrm{~V})$. In experiments with methionine as central amino acid in $\mathbf{1}$ a we observed a new intermediate 12 with $\lambda_{\max }=385 \mathrm{~nm},[16]$ an observation that is in accord with experiments of Glass et al. who suggested a neighbor group effect during oxidation of norbornene $\mathbf{1 3}$ induced by the endo amide group (Fig. 3).[20] This leads to the captodative stabilized radical $\mathbf{1 4}$, which reduces the oxidation potential of the thioether by $300 \mathrm{mV}$ and shows a UV spectrum with $\lambda_{\max }=390 \mathrm{~nm}$.

\section{Charges}

In addition to the variation of side chain X (Fig. 1), experiments with peptides where the $\mathrm{N}$-terminal amino acid is unprotected and protonated to its ammonium ion were carried out in order to investigate the influence of charges on ET processes. ${ }^{[11]}$ These experiments showed that this positive charge either reduces or increases the ET rate. The rate effect depends upon the direction of the ET steps. In assay 9 the positive charge migrates in the direction of the N-terminal end. Therefore
$\mathrm{N}$-deprotection and protonation leads to a rate decrease. The opposite effect was detected with assay 15 where the positive charge moves away from the ammonium ion of the N-terminal amino acid. This reduces the Coulomb repulsion and leads to a tenfold rate increase (Fig. 4). Interestingly, the amount of this effect can also be calculated by the Coulomb and the Marcus theory. ${ }^{[11]}$

In our newest, ongoing experiments we are investigating the influence of the secondary structure on the ET mechanism and ET rate. There are indications that with $\alpha$ or 3 -helices even the amide groups might become hopping stations because the dipole moments of the peptide dramatically influence their redox potentials. [21]

Received: March 7, 2012

[1] a) M. Cordes, B. Giese, Chem. Soc. Rev. 2009, 38, 892; b) B. Giese, S. Eckhardt, M. Lauz in 'Encyclopedia of Radicals in Chemistry, Biology and Materials', Eds. C. Chatgilialoglu, A. Studer, Wiley, Chichester, 2012, 1475.

[2] a) E. Meggers, M. E. Michel-Beyerle, B. Giese, J. Am. Chem. Soc 1998, 120, 12950; b) B. Giese, Acc. Chem. Res. 2000, 33, 631; c) E. Meggers, A. Dussy, T. Schäfer, B. Giese, Chem. Eur. J. 2000, 6, 485; d) B. Giese, J. Amaudrut, A.-K. Kohler, M. Spormann, S. Wessely, Nature 2001, 412, 318; e) B. Giese, Top. Curr Chem. 2004, 236, 27; f) B. Giese, B. Carl, T. Carl, T. Carell, C. Behrens, U. Hennecke, O. Schiemann, E. Feresin, Angew. Chem. Int. Ed. 2004, 43, 1848 .
[3] a) B. Giese, Bioorg. Med. Chem. 2006, 14 6139; b) B. Giese, M. Graber, M. Cordes, Curr Opin. Chem. Biol. 2008, 12, 755.

[4] a) M. Cordes, A. Köttgen, C. Jasper, O. Jacques, H. Boudebous, B. Giese, Angew. Chem. Int. Ed. 2008, 47, 3461; b) M. Cordes, O. Jacques, A. Köttgen, C. Jasper, H. Boudebous, B. Giese, Adv. Synth. Catal. 2008, 350, 1053; c) B. Giese, M. Wang, J. Gao, M. Stolz, P. Müller, M. Graber, Angew. J. Org. Chem. 2009, 74, 14541.

[5] The synthesis of the injector system 2 follows procedures described in a) A. Marx, P. Erdmann, M. Senn, S. Körner, T. Jungo, M. Petretta, P. Imwinkelried, A. Dussy, K. J. Kulicke, L. Macko, M. Zehnder; B. Giese, Helv. Chim. Acta 1996, 79, 1980; b) R. Glatthar, M. Spichty, A. Gugger, R. Batra, W. Damm, M. Mohr, H. Zipse, B. Giese, Tetrahedron 2000, 56, 4117.

[6] A. Gugger, R. Batra, P. Rzadek, G. Rist, B. Giese, J. Am. Chem. Soc 1997, 119, 8740.

[7] A. Heck, P. B. Woiczikowski, T. Kubař, B. Giese, M. Elstner, T. B. Steinbrecher, J. Phys. Chem. B 2012, 116, 2284.

[8] R. R. Hudgins, F. Huang, G. Gramlich, W. M Nau, J. Am. Chem. Soc. 2002, 124, 556

[9] a) M. Napp, Ph.D. thesis, Basel, 2004; b) M. Cordes, Ph.D. thesis, Basel, 2008.

[10] B. Giese, M. Napp, O. Jacques, H. Boudebous, A. M. Taylor, J. Wirz, Angew. Chem. Int. Ed. 2005, 44, 4073.

[11] J. Gao, P. Müller, M. Wang, S. Eckhardt, M Lauz, K. M. Fromm, B. Giese, Angew. Chem. Int. Ed. 2011, 50, 1926.

[12] R. A. Marcus, N. Sutin, Biochim. Biophys. Acta 1985, 811, 265.

[13] H. B. Gray, J. R. Winkler, Chem. Phys. Lett. 2009, 483, 1

[14] R. A. Malak, Z. Gao, J. F. Wishart, S. S. Isied, J. Am. Chem. Soc. 2004, 126, 13888.

[15] The measurements of $n=5$ were carried out by ET from the $\mathrm{C}$ - to the N-terminus of the PPII helix. This reaction is about 2.5 times slower than in the opposite direction, see ref. [11] The rate value of $6 \times 10^{5} \mathrm{~s}^{-1}$ takes this directional effect into account.

[16] M. Wang, J. Gao, P. Müller, B. Giese, Angew. Chem. In. Ed. 2009, 48, 4232.

[17] J. Stubbe, D. G. Nocera, C. S. Yee, M. C. Y Chang, Chem. Rev. 2003, 103, 2167.

[18] P. Faller, C. Goussias, A. W. Rutherford, S. Un, Proc. Natl. Acad. Sci. USA 2003, 100, 8732.

[19] a) C. Aubert, M. H. Vos, P. Mathis, A. P. M. Eker, K. Brettel, Nature 2000, 405, 586; b) K. Brettel, M. Byrdin, Curr. Opin. Struct. Biol. 2010, 20, 693.

[20] R. S. Glass, G. L. Hug, C. Schöneich, G S. Wilson, L. Kuznetsova, T.-M. Lee, M. Ammam, E. Lorance, T. Nauser, G. S. Nichol, T. Yamamoto, J. Am. Chem. Soc. 2009, 131 13791

[21] a) T. Herz, P. Otto, T. Clark, Int. J. Quantum. Chem. 2000, 79, 120; b) X. Chen, L. Zhang, L. Zhang, W. Sun, Z. Zhang, H. Liu, Y. Bu, R. I. Cukier, J. Phys. Chem. Lett. 2010, 1, 1637; c) Y. Arikuma, H. Nakayama, T. Morita, S. Kimura, Angew. Chem. Int. Ed. 2010, 49, 1800. 